IRA-International Journal of Management \& Social Sciences

ISSN 2455-2267; Vol.06, Issue 03 (2017)

Pg. no. 384-390

Institute of Research Advances

https://research-advances.org/index.php/RAJMSS

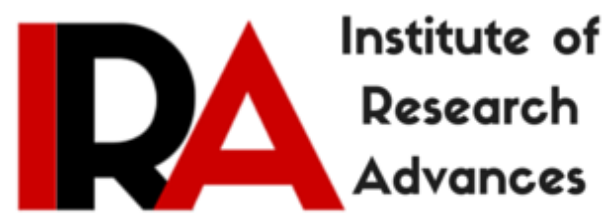

\title{
Highlighting Tribal Tourism Potentials of Southern Rajasthan
}

\section{Suneeta Verma ${ }^{1}$}

Research Scholar, Pacific university of Hotel Management, Pacific University, Udaipur, Rajasthan, India.

\section{Dr. Madhu Murdia ${ }^{2}$}

Associate Professor, Pacific University of Hotel Management, Pacific University, Udaipur, Rajasthan, India.

Type of Review: Peer Reviewed.

DOI: http://dx.doi.org/10.21013/jmss.v6.n3.p5

\section{How to cite this paper:}

Verma, S., \& Murdia, M. (2017). Highlighting Tribal Tourism Potentials of Southern Rajasthan. IRA-International Journal of Management \& Social Sciences (ISSN 2455-2267), 6(3), 384-390. doi:http://dx.doi.org/10.21013/jmss.v6.n3.p5

(C) Institute of Research Advances

\section{(c)) EY-NO}

This work is licensed under a Creative Commons Attribution-Non Commercial 4.0 International License subject to proper citation to the publication source of the work.

Disclaimer: The scholarly papers as reviewed and published by the Institute of Research Advances (IRA) are the views and opinions of their respective authors and are not the views or opinions of the IRA. The IRA disclaims of any harm or loss caused due to the published content to any party. 


\begin{abstract}
Tribes are very mysterious; everything about them is still unexplored and unspoiled. This research paper highlights potential for the promotion of tribal tourism and various tribes inhabiting in these tribal areas. Further it discusses a strategy to develop a new tourism product to match up with the growing expectations of the tourists in southern Rajasthan. For this, various tourism potentials like their history culture, costume, cuisine etc. have been studied. Further in this paper it has been discussed that tribal tourism is responsible for the positive image building and exploring the unidentified locations of our beautiful and multifaceted state. These days' tourists are in thrust for new experiences, innovations and adventures. It would be wrong to underestimate that tourists are not willing to experience new cultures and face new challenges of these mysterious tribes.

Before writing this paper extensive literature review has been done. The literature review was divided into 3 phases. It consists of extensive survey of literature, profiling the entertainment possibilities for the tourists and finally providing a strategy for the development of tribal tourism in Rajasthan.
\end{abstract}

Key words: Tribes of Rajasthan, Bhil, community development, sustainable tourism.

\title{
Introduction
}

Southern Rajasthan has got rich diversity of tourism resources. This area has beautiful mountains chiseled by deep picturesque valleys where many tribe are found. It has beautiful gardens, palaces, religious centers, waterfalls and lakes. Beside this, Southern Rajasthan is pollution free and has got rich history and culture. It also offers pilgrimage, adventure, culture, and leisure and heritage tourism. The beautiful and mysterious Aravali is home to some of the most beautiful valleys like in Kumbalgarh and Ranakpur area. They also offer various types of flora and fauna and wildlife. Entertainment possibilities in the Aravali for tourists are as per the below:

- $\quad$ Trekking

- Camping

- Jungle Safari

- Hot air balloons

- Leisure and pleasure

- Scenic beauty etc.

Among all these opportunities to explore and experience travel pleasures, tourists are still looking for new involvements. Here, introduction of tribal tourism will help in filling up that expected space. Tourism products in tribal areas are still untouched and unexplored. Earlier, tourists were considered to be looking for modern amenities while visiting tourism destinations. But now they are willing to travel to satisfy their urge to know about unknown and shadowy stuffs. When talking in the present context, globalization has bought rapid changes in our lives. Globalization has not only increased our tolerance, knowledge about the culture of various communities but it has also raised the curiosity level in us.

In this research paper, a detailed description has been given to develop tribal tourism in southern Rajasthan and its potential to satisfy the growing curiosity among tourists. Mainly southern Rajasthan is inhabited by six tribes. These tribes have been here since centuries and their roots are spread all around the state of Rajasthan. They have rich cultural history, old and unique traditions, rich beliefs and rituals. Their art and craft are handmade and use natural products; Simple lifestyle with exotic fairs and festivals. They are innocent and peace loving people who are still unaffected from the developed and metro culture. Tourists looking for peaceful, relaxing and yet adventurous stay will surely be benefited after visiting these location. Various tribes inhabiting Sothern Rajasthan are as per below: 
Bhil: Bhil are the second largest tribal group in Rajasthan and constitute about $42.12 \%$ of the total tribal population in Rajasthan. The term Bhil is derived from Dravidian term vil. They are mainly found in the southern districts of Rajasthan that is in Banswara, Dungarpur, Udaipur and Chittorgarh. Their language is Bhili, which is an Indo- Aryan language. They are skill full warriors who are apt in guerilla warfare and history corroborates various legends of their superiority in archery. For instance, Eklavya in Mahabharata, a Bhil who surpassed skills of Arjuna, and similarly Valmiki a renowned poet from Ramayana was also a Bhil bandit who was reformed with the blessings from goddess of knowledge Saraswati. Even the Rajput rulers shot their help to fight against Muslim and Maratha attacks. Even today, Maharana of Udaipur is crowned by anointing his forehead with blood drawn from palm of Bhil chieftain. This act affirms their alliance and loyalty of tribe for the Maharana. The traditional dress of Bhil is very colorful and eyecatchy.

Meena: One of the largest scheduled tribes of Rajasthan constituting 51.13\% of the total tribal population of the state and are widely spread. In the north, they inhabit the Jaipur-Sikar belt of Shekhawati, continuing into Alwar district in the southwest; the Minas settlements mix with the Bhils of Bundi-KotaJhalawar Meenas were the originl inhabitants of pre-historic Indus valley civilization. According to the legends, they are believed to be originated from fish. According to the Vedas they were enemies of Aryans. Their glory is recorded in the kingdom of Matsyaraj in Mahabharata.The Kachhawaha clan of Rajputs finally defeated them and they had to relegate in forests and hilly areas of Aravalis.

Garasia: The third largest tribal group in Rajasthan. They are mainly concentrated in Abu Road tehsil of Sirohi, Kotra, Gogundaand Kherwara tehsils of Wdaipur,Bali and Desuri tehsils of Pali district and some in Dungarpur district. The word Garasia is derived from Sanskrit word "gras" that is substance.According the legend the Garasia tribal are descendants from the Chauhan Rajput's of south-west Rajasthan. May be due to their origin their culture have a semblance of Bhil culture. But due to their beginnings as fallen Rajputs give them a higher status than the aboriginal Bhil. Their dress are very colourful and with lots of embroidery.

Saharia: This tribe is only primitive tribal group (PTG) of Rajasthan also known as "The Jungle dwellers or residents of jungles. As per 1991 census, Saharia constitute 59,810 souls (23.98\% of the total population of Saharia tribe in India) in Rajasthan. They are mainly concentrated in Shahbad district of Princely state of Kota, Kishanganj Panchayat samities of Baran district and neighboring regions of Jhalawar, Sawai Madhopur, Dungarpur and Udaipur. Some scholars believe that the world Saharia is derived from Arabic word Sehara meaning wildness while there are others who believe that it has been derived from the Persian word Sahr meaning the desert jungle or forest. Their rituals and food habits are like Hindus barring few exceptions. They live in joint families and child marriage in not favored among them. Widow marriage called Nat is permitted but only to a widower or a divorcee The Sahariyas worship Hindu gods and Goddesses.

Damor: Generally found in Simalwada, Sagwara and Aspur tehsils of Dungarpur and some villages of Banswara and Udaipur as well. Men wear white dothi, kamij(shirt) and safa (turban) over their head. Whereas women wear ghaghra (skirt) or petticoat, kanchi(short blouse) kabja (blouse) lugda (upper garment). Damor ladies wear stuffs made of silver, gold and beads. And normally they wear earrings, nose pin, bangles, armlets neck band, necklace, tow rings and anklets. Totting is also common in them. 
Kathodi: Also known as Katkari and etymologically, kathodi means catechu makers and Katkari stands for people expert in felling trees. They are mostly found in Jhadol and Kotra panchayat samities of Udaipur district. Their huts are known as Kholra and it is made out of straw, grass with bamboo poles. Traditional dress for men is dhoti (loin cloth), kurta(shirt) and phenta (turban). Whereas kathodi women wear sari and polka(blouse). Common ornaments for kathodi women are bead necklace, silver nose pin and glass bangles. Tattooing on face for them is a special feature.

\begin{tabular}{|c|c|c|c|c|}
\hline Tribe & Male Dress & Female Dress & Male Ornaments & Female Ornaments \\
\hline Bhil & $\begin{array}{l}\text { Angrakhi } r \text { or } \\
\text { jhangi (tight } \\
\text { shirt), potario or } \\
\text { lion cloth and } \\
\text { pagdi or turban }\end{array}$ & $\begin{array}{l}\text { Angrakhi or } \\
\text { jhalki(blouse) with } \\
\text { sleeves, ghaghra or } \\
\text { skirt and lungra }\end{array}$ & 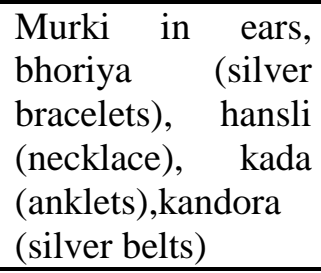 & $\begin{array}{l}\text { Silver bor, pejania (brass } \\
\text { anklets), bichiya (toe ring), } \\
\text { ear rings, finger ring, } \\
\text { necklace, neckband, and nose } \\
\text { ring. }\end{array}$ \\
\hline Mina & $\begin{array}{l}\text { Dhoti (lion cloth), } \\
\text { kurta or loose } \\
\text { shirts or bandi } \\
\text { (tight shirt) }\end{array}$ & $\begin{array}{l}\text { Ghaghra (skirt), } \\
\text { odhni, kabja and } \\
\text { kanchli }\end{array}$ & $\begin{array}{l}\text { Murki (ear rings) } \\
\text { and kada }\end{array}$ & $\begin{array}{l}\text { Bor, ear ring (kundal or } \\
\text { jhumki), khungali, hansli } \\
\text { (necklace), bajubandh } \\
\text { (armlet), kangan, kadachudia } \\
\text { (bangles), anguthi (ring), } \\
\text { kade, nevin, anklet, } \\
\text { bichhuechutki (toe ring) }\end{array}$ \\
\hline Garasia & $\begin{array}{l}\text { Safa or potiyu, } \\
\text { white } \\
\text { (jhulki) with half } \\
\text { sleeves } \\
\text { dhotis, pacheroo }\end{array}$ & $\begin{array}{l}\text { Gherdarghaghra, } \\
\text { jhulki and odhni }\end{array}$ & $\begin{array}{l}\text { Jhelajharmariyu, } \\
\text { kada, kandora and } \\
\text { hakali }\end{array}$ & $\begin{array}{l}\text { Earring (kundal or jhumki), } \\
\text { khungali, hansli (necklace), } \\
\text { bajubandh (armlet), kangan, } \\
\text { kadachudia (bangles), anguthi } \\
\text { (ring), kade, nevin, anklet, } \\
\text { bichhuechutki (toe ring) }\end{array}$ \\
\hline Saharia & $\begin{array}{l}\text { Dhoti, saloko or } \\
\text { kurta and safa or } \\
\text { turban }\end{array}$ & $\begin{array}{l}\text { Ghaghara, odni, } \\
\text { kachuli, saree and } \\
\text { kabja }\end{array}$ & $\begin{array}{l}\text { Chain, murkhi and } \\
\text { kada }\end{array}$ & $\begin{array}{l}\text { Churi (glass bangles), chura } \\
\text { or armlet and bichia (toe ring) }\end{array}$ \\
\hline Damor & $\begin{array}{l}\text { Dhoti (loin cloth), } \\
\text { kamij (shirt) and } \\
\text { safa (turban) }\end{array}$ & $\begin{array}{lr}\text { Ghaghara } & \text { (skirt), } \\
\text { or } & \text { petticoat, } \\
\text { kanchli } & \text { (short } \\
\text { blouse), } & \text { kabja } \\
\text { (blouse) } & \text { lugda } \\
\text { (upper garment) }\end{array}$ & Silver chain, kada & $\begin{array}{l}\text { Earring, nose pin, bangles, } \\
\text { armlets, neck band, neck lace, } \\
\text { toe rings and anklets. }\end{array}$ \\
\hline Kathodi & $\begin{array}{l}\text { Dhoti (loin cloth) } \\
\text { or trousers and } \\
\text { half pants, } \\
\text { kurta(shirt) and } \\
\text { phenta (turban) }\end{array}$ & $\begin{array}{l}\text { Sari and polka } \\
\text { (blouse) on } \\
\text { Maharashtraian } \\
\text { pattern }\end{array}$ & N/A & $\begin{array}{l}\text { Bead necklace, silver nose pin } \\
\text { and glass bangles, earrings, } \\
\text { bichhue (toe ring) }\end{array}$ \\
\hline
\end{tabular}

Dress and ornaments of tribal males and females

Source: Glimpse of Tribal Rajasthan

\section{Objective of the study}

Tribal tourism is an emerging niche in the field of tourism. It has a lot of potential in Rajasthan. But till now a very little has been done to promote and develop this interesting aspect. The objectives of this study are: 
i. Highlighting scope of tribal tourism

ii. Analysis of tribal of interest in Southern Rajasthan

iii. Developing a strategy for tribal tourism development.

\section{Research methodology}

This article is based on secondary data taken from related literature review and internet sources. The content was compiled and analyzed to build up a new concept of tribal tourism in southern Rajasthan. The research methodology was divided into 3 phases:

\section{PHASE 1: Extensive survey of literature.}

\section{PHASE 2: Profiling the entertainment possibilities for the tourists.}

\section{PHASE 3: Providing a strategy for the development of tribal tourism in Rajasthan.}

\section{Literature Review}

An extensive literature survey was done for this research paper about the history, culture, traditions and life style of tribes living in southern Rajasthan.

Lilang, Tbulan, and Hrung (2013) in their study in Taiwan Chu-Chu Liao, concludes that Indigenous (tribal) tourism is resource-based, and their culture works as a major tourist attraction. The beautiful natural landscapes should be developed along with tourism in such areas. The exotic landscapes and their people may work as catalyst to attract tourists. ${ }^{1}$

Ward, Terry (2010) suggests in his study, that "Tribal tourism refers to a new form of travel in which tribes allow tourists to visit their villages in order to be "exposed to a culture completely different from their own." Recently, this opportunity of experience "authentic" native life style has grown immensely throughout the world. Especially in Latin American nations with large indigenous communities, such as Peru, Brazil, and Guatemala tribal tourism has started making progress on international level. He also discusses about the financial opportunities that have been created for tribes. He concludes that tribal tourism has helped foster awareness among indigenous people, who have been facing oppression, forced land relocation, and challenges to social and economic integration. ${ }^{2}$

In the year (2004) Brittion states on emphasizing development in local communities from tribal tourism. He concludes that tourism plays very important role in reducing inequalities and redistributing social goods. ${ }^{3}$

Van Broeck (2001) presents his opinion in his study about the residents of south-west Turkey. He states that locals (residents) welcome tourism because of money (income) generated fromtourism development in Pamukkal. The material and infrastructure development due to tourism was an added advantage. Further, he concludes that sustainable development of tourism improves the living conditions, position of women and community bonds among the others. ${ }^{4}$

As per Cukier (1998) tourism development will help in increasing employment opportunities and as well as associated job prospects for the locals. These new scenarios may work as major economic benefits for tribal. And it will surely help in improving the living standards, reducing poverty in these developing communities. ${ }^{5}$

Similarly, various others have agreed that tourism development in rural and tribal areas will help in uplifting the local residents. But for developing tribal tourism in tribal areas it is very important that the adverse effects are minimized and the benefits coming from it are maximized. With this prevention of environment, natural landscapes, wildlife, flora and fauna should also be taken into consideration. 


\section{Entertainment possibilities for the tourists:}

Tribal Fairs and festivals attract tribes not only from the state but also from the neighboring states like Madhya Pradesh, Gujarat and Maharashtra. The main tribal fairs that are celebrated among them are, Keshriyaji, Goutameshwar, and Baneshwar. Tribal Festivals are not only very colourful but are celebrated with great pomp and show. All the community gather together to participate in dances, music and religious rituals and programs. Main festivals which are celebrated among tribals are Gangaur, Akhateej, Deepavali, Ekadashi/Gayaur and Holi.

Generally their dress (costumes) is very colourful. Male coustume includes a pagadi (turban) and females love to wear jewelry. Tribal costumes and jewelry are attractions in themself. The jewelry's are handmade and are quite beautiful and unique. Tribal Cuisine is mostly forest products.

Most of the tribal locations are far away from the busting cities. These locations are full of scenic beauty and adventures. Their location in itself is quite attractive, the beautiful valley, meadows, clean environment and flora and fauna.

Tribal traditions and customs are strange for the outsiders but are very important to the tribal. Tribal are denoted to oldest ethnological groups and since they live away from the civilized world they have succeeded in preserving their unique customs and rituals. Tribal art and paintings are not sophisticated but it is unique in nature and very fine. In today's market they are of great value. These are handmade and the products used to make them are natural.

\section{Strategy for tribal tourism development in southern Rajasthan:}

In this research paper an attempt has been made to highlight the untapped potential of tribal tourism in southern Rajasthan. There is no doubt that Rajasthan has done exceptionally well in tourism till now but still a strategy for new products must be developed to keep the tourist in-flow both domestic and international steady and regular. Tribal tourism is still in its very nascent stage. Rajasthan has immense potential to attract tourists but it still needs to develop tribal tourism as per the requirement of the tourists and as well as locals.

There are mainly 6 tribes in Rajasthan as mentioned above. And to promote tribal tourism as a tourism product, a proper strategy needs to be formulated so that good policies can be developed. Tribal and tourists both are needed to be informed about it. This information can be given through visitor centers, tribal research institutes (TRIs), tribal tourism books and guides. With this technology can also be used like audio films and brochures etc.

But this will not be enough, special training workshops should be arranged for tour operators/ travel agents/guides/ taxi operators/ Hoteliers and others directly or indirectly involved in tourism industry to generate awareness about tribal tourism potential, its sites and requirement. The involvement of researchers in this field and tourism professionals can further enhance the educational value and cultural importance of these tribes. For this, it is proposed for the development of TTDCs (Tribal Tourism Development Centers). The development of tribal tourism should be done keeping in mind sustainable planning and development. We need to capitalize the available resources to produce the maximum optimum result. Tribal tourism can surely act as a sector for the development of tribal by providing a source of employment. But before that, these tribal locations need to be made assessable.

After this other amenities such as transportation, accommodation, connectivity, food and beverages and safety need to be developed. To develop tribal tourism in Rajasthan, we need suitable marketing and promotional strategies. All these things need to be done on sustainable and ecofriendly basis limiting the negative impacts. 


\section{Findings and Suggestions}

There are ample of resources present in Southern Rajasthan for the development of tribal tourism. Only, now is need to take one step forward and supplement the concept with proper utilization of all its tribal resources like locals, their custom and traditions, fair and festivals, music and dances, religion and rituals. With this it should be kept in mind that while developing tribal tourism the tribal should not be harmed and their ethnicity should be maintained. For the proper development of tribal tourism in southern Rajasthan few steps should be taken. Like:

i. Generating a catalogue of tribal resources.

ii. Positioning the tribal locations on the tourism map of the state. For this proper profiling of such locations should be done with tourism perspective.

iii. Familiarization trips should be organized

iv. Traveling exhibitions and awareness campaigns along with marketing will also help to popularize this concept.

v. The creation of TTDCs (tribal tourism development centers) will also create positive attitude and interest.

\section{Conclusions}

After extensive study of available literature and data it can be concluded that tribal tourism can be a new concept. Presently, it is in its introductory stage only and surely no efforts have been made to understand its importance or develop it for international tourists. But a sustainable development of this product will ensure the uplifting of tribes and will generate a new concept for tourists coming to Rajasthan. The growing demand of rural tourism is not enough to contain the growing curiosity of the tourists. Tribes have always given something or other to the society in every era and now it's time for us to do something for them. With the development of tribal tourism in Southern Rajasthan, tribes, researchers and tourism professionals all will benefit.

The community participation and involvement may be a new approach for the development of tribal tourism in these areas. And sustainable development of tribal tourism will help in maintaining the cultural and historical identity of the locals. Development of tourism in southern Rajasthan will create new opportunities for tribal to benefit from it and attaining better opportunities.

\section{References}

1. Lilang, Tbulan, and Hrung (2013) A Study of Indigenous Tribes Tourism Developing-Case in Taiwan Chu-Chu Liao, Ying-Xing Lin, World Academy of Science, Engineering and Technology International Journal of Social, Behavioral, Educational, Economic, Business and Industrial Engineering Vol:7, No:11, waset.org/Publication/9996584

2. Ward, Terry (2010), "Tribal Tourism: Ethical or Exploitative?," http://news.travel.aol.com/2010/12/08/tribal-tourism-ethical-or-exploitative/ (as on July 2, 2014)

3. Britton, Stephen. (2004). Tourism, Dependency, and Development: A Mode of Analysis, in Tourism: Critical Concepts in the Social Sciences, Volume III: Tourism, Development, and Sustainability by Stephen Williams, ed. 29-37. London, New York: Routledge.

4. Van Broeck, A. M. (2001). Pamukale: Turkish Homestay Tourism. Hosts and Guests Revisited: Tourism Issues of the 21st Century, eds. Valene L. Smith and Maryann Brent. New York: Cognizant Communication Offices.

5. Cukier, Judith. (1998). Tourism Employment and Shifts in the Determination of Social Status In Bali. Destinations: Cultural Landscapes of Tourism, ed.Greg Ringer. London, New York: Routledge 